\title{
The effect of internal audit effectiveness, auditor responsibility and training in fraud detection
}

\author{
George Drogalas ${ }^{\mathrm{a}, 1}$, Michail Pazarskis ${ }^{\mathrm{b}}$, Evgenia \\ Anagnostopoulou $^{\mathrm{a}}$, and Angeliki Papachristou ${ }^{\mathrm{b}}$ \\ ${ }^{a}$ University of Macedonia, Greece \\ ${ }^{\mathrm{b}}$ T.E.I. of Central Macedonia, Greece
}

\begin{abstract}
The purpose of this study is to explore the relationship between internal audit effectiveness, internal auditor's responsibility, training and fraud detection. During the last decade internal auditing has become an integral part of modern businesses since it is capable of detecting errors or offences which lead to fraud. In order to investigate the above relationship, we conducted a survey of companies listed in the Athens Stock Exchange. We used factor analysis to validate the survey instrument and to construct our variables measuring fraud detection, internal audit effectiveness, auditor responsibility and training. We used regression analysis to test for significance between the constructed variables. Our analysis shows that audit effectiveness, auditor responsibility and auditor training affect positively and significantly the detection of fraud. Our results highlight the importance of internal audit in detecting accounting fraud and the need of companies to invest on internal audit processes and training in order to achieve enhanced corporate performance. Finally, our research stresses the importance of internal audit and fraud detection for companies which operate in countries which are in a period of economic crisis.
\end{abstract}

Keywords: Internal audit, auditor responsibility, auditor training, fraud detection, accounting fraud.

JEL codes: M40, M41, M42

${ }^{1}$ Corresponding author: George Drogalas, Assistant Professor, Department of Business Administration, University of Macedonia, 156 Egnatia Str., Thessaloniki, Greece, Tel: 00302310891537, e-mail: drogalas@uom.gr 


\section{Introduction}

Worldwide, demand for fraud audit services has increased over the last years (Westhausen, 2017). The financial crisis and instability have resulted in the increase of fraud scandals, making the use of internal auditing procedures of outmost importance for companies (Bekiaris et al., 2013). Fraud auditing is a relatively new field, which involves extensive testing procedures of cases of economic crime such as falsifying of financial data, misappropriation of assets, investment fraud, bribery or fraudulent transfer of electronic funds. Internal audit is also an important part of modern business because it contributes to the achievement of an organization's objectives by adopting a systematic and disciplined approach to assessing and improving effective risk management, control and governance processes (El-Sayed Ebaid, 2011). The effectiveness of internal auditing can improve from the quality of internal audit, the competence of internal audit team, the independence of internal audit and the management support (Drogalas et al., 2015). In this context, the internal auditor is responsible for detecting financial errors and specifically by using the auditing standards (Bedard et al., 2015). Finally, it is worth to mention that the role of internal auditor depends on his practical abilities and professional training in detecting fraud (Petrascu \& Tieanu, 2014).

Despite the importance of internal audit in fraud detection, majority of research analyzes the part of internal audit and its effectiveness, not the responsibility of the internal auditor to detect fraud. Our research is conducted in the context of Greek business. The selection of the Greece as target population for our research stems from the importance of fraud detection for the Greek economy. Greece has been in a deep recession during the last decade and there is currently a large amount of hidden financial crime and fraud which has a negative impact on the economy (Krambia-Kapardis \& Papastergiou, 2016). In this context, the aim of this study is to examine fraud detection and internal audit and namely whether it is positively influenced by internal audit effectiveness, internal auditor responsibility and internal auditor training in Greek companies. The present study also seeks to provide additional evidence comparable to the results of other research.

Our methodology involves the analysis of the above concepts through the processing of data collected with the use of survey instruments. We used factor analysis to validate the survey instrument and to construct our variables measuring fraud detection, internal audit effectiveness, auditor responsibility and training. We used regression analysis to test for significance between the constructed variables. Our results suggest that audit effectiveness, auditor responsibility and auditor training affect positively and significantly the detection of fraud in Greek companies. Overall, this paper contributes to the literature by complementing recent qualitative studies in this area that suggest the increased importance of the relationship between the internal audit function and fraud detection. The main 
contribution of this study is the construction of the factors that measure the variables described above the examination of their importance in the detection of fraud. The findings of the study are important from a theoretical perspective because most prior literature on aspects of internal audit function has not focused on empirical evidence regarding Greek context. Also, the findings of the study are important from a practical perspective, as they can help managers and internal auditors to improve the internal audit procedures of their companies and achieve increased detection of financial fraud.

The remainder of this paper is organized as follows: Section 2 presents the literature review and our research hypotheses. Section 3 describes the data and the methodology used in this research. Section 4 presents the empirical results of our research and section 5 the conclusions and the recommendations for future research.

\section{Literature review}

\subsection{Detection of fraud and internal audit}

Financial fraud has many aspects and penetrates deep into many activities, as Nardo (2011) concludes, following the investigation and analysis of the characteristics and mechanisms of the informal economy. What is important is the constant vigilance and investigation, checking all activities within an organization and taking action where misconduct is found. According to Rezaee (2005), financial accounting fraud is a deliberate act to mislead corporate stakeholders, especially investors and creditors, by misrepresenting or omitting accounting data, which results in inaccurate financial statements. The American Institute of Certified Public Accountants, according to SAS 99 standard, regards falsification of financial statements as fraud, through the deliberate negligence or misstatement of financial accounts. Additionally, Spathis (2002) reports that in the US the greatest falsification of accounts have been recorded (in large enterprises), the term that is mainly used is fraud and interpreted as a deliberate distortion of the financial statements.

The most sensitive issue for businesses is the cost of fraud, which was studied by Button et al. (2015) in businesses in the UK. Through this research the cost subjected to the companies was assessed after the discovery of fraud by an employee or employees of the companies themselves. The costs of fraud relate to the expenses of investigating fraud, whatever other costs incurred in dealing with it, external sanctions and the new staff search. The amount is about 25,000 pounds for frauds whose value was below this amount and it seems that in general the remediation cost for the damage caused is much more than the amount stolen, 
which is a great detriment to the company. Based on the above, we conclude to the general assumption that fraud detection plays an important role in managing a business.

Regarding accounting misrepresentations, various methods are used which are included in the term imaginative book (creative accounting). Along those lines, creative accounting has been studied by Balaciu et al. (2014), where they investigated the possible way in which managers can develop their relations with auditors so that they will change the accounting policy that can bring benefits to the firm. These two can collaborate so the auditors will draw attention on danger of fraud. According to the American Institute of Certified Public Accountants AICPA, internal auditing includes the efforts, methods and measures adopted within an organization in order to secure and protect its assets, control accuracy and reliability of its accounting data, promote efficiency of its operations and encourage the maintenance of the its standard business policy.

Many companies have invested substantial funds in internal auditing during the last decade. In their article Carcello et al.(2005) show that enterprises and with a large debt have a high budget for internal auditing. Also, companies that provide financial services or utilities as well as companies with high cash flows use internal auditing processes in order to oversee the budgets and the financial transactions made within the company. Omoteso and Obalola (2014) investigated Porter's approach to the control regarding the "Audit Trinity" according to which the internal auditing, external auditing and the auditing committee in collaboration, the investigation and management of corporate fraud. They mention the relations that must exist between these three types of control so that they can support a healthy internal control system as a tool for preventing and detecting fraud. Therefore, the internal auditors protect the financial data of the enterprise, the external auditors check on companies for the protection of society and the auditing committee monitors and supervises both for their effective operation in fraud detection.

Moreover, SAS No. 82 (paragraph 3) highlights the role of auditors concerning the detection of fraud. The same model in paragraphs 4-10 underlines two main risk factors, 1) the falsification of accounts, and 2) the incorrect valuation of assets of the company (Gaganis \& Zopounidis, 2008). Finally, Krambia - Kapardis and Papastergiou (2016), in their research of fraud in Greek companies, show that all companies, regardless of their size, have been victims of fraud, especially industrial espionage theft of cash and counterfeit cash, money laundering and theft of assets. They conclude that as the Greek crisis continues, companies need to take preventive measures against fraud through the internal auditing of their activities. 


\subsection{Internal auditing efficiency and detection of fraud}

Detecting fraud is undoubtedly difficult, however not impossible. In their research, Lendez and Korevec (1999) point out that it is more efficient for an enterprise to effectively prevent fraud first, through management, thereby creating a positive control environment and then recruiting trusted individuals in the internal auditing department. These individuals will be trained in fraud and will implement preventive measures through various processes to help identify fraud more easily. According to Petrascu and Tamas (2013), the role of internal control is to ensure that the company's financial data complies with the accounting principles and practices and to present an accurate, clear and complete picture of the financial statements. To ensure the above, an effective system of control should be implemented in order to identify and limit irregularities and fraud. Moreover, a healthy relationship between internal auditing, external auditing and the auditing committee can also develop an internal control system with a proper structure that helps in the suitable operation of the business and effectively contributes to the detection and management of fraud (Omoteso \& Obalola, 2014).

The positive relationship between effectiveness of internal audit and detection of fraud is also confirmed by the results of research conducted by Monisola (2013), in which the existence of internal audit department in a business organization increases corporate control of errors, irregularities and fraud. Finally, Coram et al. (2008) find that companies with established internal audit functions detect much more acts of fraud than companies that do not have an internal audit department. Based on the above we form the following hypothesis:

H1: There is a positive relationship between internal auditing effectiveness and fraud detection.

\subsection{Internal auditor responsibility and detection of fraud}

According to DeZoort and Harrison (2008) detection of fraud is strongly related to the personal responsibility of the internal auditor, which includes the establishment of clear and precise audit regulations, the feeling of professional obligation and the connection the internal auditor has with the fraud event and how can his actions control it. Moreover, auditors, who are accountable of their reports, present a higher degree of detection responsibility than anonymous auditors. In another study, Balaciu et al. (2012) in investigating the behavior of auditors regarding creative accounting practices on affecting the financial assets, they find that the main objective of the auditors is not only to find frauds and errors but to evaluate the efficiency of the internal auditing and making recommendations that aim to prevent and track fraud and errors. 
Vanasco (1998) investigated how of fraud is dealt with by the internal auditor. He examines several cases of fraud and the impact of management and fraud on the various business areas such as insurance, banking, health care, and construction, as well as the role of management, boards of directors, auditing committees, auditors and their responsibility to prevent fraud. According to the above research, when the internal auditor becomes aware of fraud he should collect the necessary information to identify the conditions and parameters under which the fraud has occurred so that he can gain a complete picture of the incident. A similar research by Hillison et al. (1999), reports that the internal auditor is the main line of an antifraud defense. In this article, the writers identify the risks of fraud and the signs that internal auditors have to recognize. Assistance to internal auditors may be provided by external auditors who can help in fraud prevention, deterrence, detection, and reporting, but as it is shown on the above research the external auditor identifies only 5\% of the frauds. For this reason, the internal auditor should: assess the auditing framework, identify fraud indications and identify weaknesses that could facilitate fraud, recommend investigations and audits and communicate the audit results to members of administration. Building on the above we formulate the following hypothesis:

H2: There is a positive relationship between internal auditor responsibility and fraud detection.

\subsection{Internal auditor training and detection of fraud}

In order for internal auditing to be efficient, it requires the continuous training of the internal auditors. The internal auditor is a person with know-how, high level of knowledge, skills and abilities, and by following international auditing standards, ensures more effective control (McKee, 2006). The detection of fraud is difficult and one reason why internal auditors find it difficult to trace and detect irregularities is because they do not have enough experience in identifying falsified financial data (Hammersley et al., 2011). Fraud training involves simulation of fraud cases which helps internal auditors gain significant experience (Bierstaker $e t$ al.,2012), increase their performance and improve their ability to detect evidence that indicate fraud.

In their research on the current control practices of copying with employee fraud and business risk, Zanzig \& Flesher (2011) compared the fraud detection conditions of US and Canadian firms to the desirable conditions in relation to fraud risk management training, understanding of fraud management procedures, recognition of key fraud indicators and incentives for reporting fraud. They conclude that training employees to manage fraud risk is the most important business practice that needs to be improved. Finally, Bierstaker et al. (2012) examined the impact of auditor training on detecting fraud. A comparative survey was conducted, with auditors attending courses focusing solely on fraud detection, 
and the other auditors attending general courses on internal auditing. After examining the auditors participating in the courses, they found that auditors who attended the courses on fraud were more likely to detect it in contrast to those who attended more general auditing course. According to the above we formulate the following hypothesis.

H3: There is a positive relationship between internal auditor training and fraud detection.

\section{Methodology}

The aim of this research is to examine the relationship between fraud detection, internal audit effectiveness, internal auditor responsibility and internal auditor training. Internal auditing is applied by listed companies on the stock exchange by law, because they have large cash flow and are more susceptible to fraud. For this reason we decided to conduct our research on these companies, regardless of their business sector of activity. By using this target population, useful conclusions can be drawn for the proper use of internal auditing in fraud detection. For our empirical research an online questionnaire was created, which was sent to companies listed in the Athens Stock Exchange. The questions included in the questionnaire were of closed type, and in particular on a five-level Likert scale. The respondents were asked to state their degree of agreement or disagreement on a number of questions regarding the subject of the internal auditing and fraud detection.

The questionnaire was divided into five sections. The first section examines the demographics of the respondents. The second section refers to the detection of fraud, the third section to internal audit effectiveness, the fourth section to the internal auditor responsibility and the fifth section to internal auditor training. The questionnaires were sent via email. In total, 207 questionnaires were sent and 112 complete questionnaires were received, representing a response rate of $54.10 \%$. To increase response rate, three reminders were sent to each target respondent. The first was after one week from the initial email posting, the second after two weeks from the initial posting and the third after three weeks from the initial email posting. The collection of questionnaires began on August 21, 2017, and completed on the September 22, 2017. The descriptive statistics of the final sample are presented in Table 1 . 
The effect of internal audit effectiveness, auditor responsibility and training in fraud detection

Table 1: Demographics of respondents

\begin{tabular}{lcc}
\hline Demographics of respondents & Frequency & $\mathbf{( \% )}$ \\
\hline Type of organisation & 6 & \\
Oil \& Gas & 4 & $5.36 \%$ \\
Chemicals & 13 & $3.57 \%$ \\
Metals \& Mining & 18 & $11.61 \%$ \\
Building Materials & 13 & $16.07 \%$ \\
Industrials & 9 & $11.61 \%$ \\
Food and Beverages & 11 & $8.04 \%$ \\
Personal Products & 4 & $9.82 \%$ \\
Health Care & 4 & $3.57 \%$ \\
Utilities & 15 & $3.57 \%$ \\
Banks & 4 & $13.39 \%$ \\
Real Estate & 11 & $3.57 \%$ \\
Other & $\mathbf{1 1 2}$ & $9.82 \%$ \\
\hline Total & & $\mathbf{1 0 0 . 0 0 \%}$ \\
\hline Positions of respondents & 16 & \\
Employee & 53 & $14.29 \%$ \\
Internal auditor & 38 & $47.32 \%$ \\
Manager & 5 & $33.93 \%$ \\
Other & $\mathbf{1 1 2}$ & $4.46 \%$ \\
\hline Total & & $\mathbf{1 0 0 . 0 0 \%}$ \\
\hline Education of respondents & 8 & \\
Technological Institute Degree & 20 & $7.14 \%$ \\
Bachelor's Degree & 71 & $17.86 \%$ \\
Master's Degree & 13 & $63.39 \%$ \\
PhD Degree & $\mathbf{1 1 2}$ & $11.61 \%$ \\
\hline Total & $\mathbf{1 0 0 . 0 0 \%}$ \\
\hline
\end{tabular}

The quality of a questionnaire is generally measured by conducting validity and reliability analysis. According to Hair et al. (1995) validity is the degree to which a measure accurately represents what it is supposed to. Reliability analysis indicates the extent to which repeating the same survey procedure yields the same results (Carmines and Zeller, 1979). Regarding the validity of our questionnaire, we used construct validity, because we want to focus on the convergence between the items included in the questionnaire and how these items can be separated and reorganized in new constructs that can accurately measure different theoretical aspects (Forza, 2002). 
The most common method in examining construct validity is the use of factor analysis (Nunnaly, 1978; Saraph et al., 1989). There are two types of factor analysis, exploratory factor analysis and confirmatory factor analysis. In this research, we are going to use exploratory factor analysis because our questionnaire has not been previously validated by other researchers. Thus, exploratory factor analysis will allow us to better understand the structure of our variables, to measure the accuracy of our survey results. Moreover, it will help us to reorganize our initial variables, into a new set of variables, which will make the original information more manageable (Field, 2013). Finally, in order to test our hypotheses we develop the following dependency model

$$
\mathrm{FD}=f(\mathrm{IAE}, \mathrm{IAR}, \mathrm{IAT})
$$

The above model was empirically estimated using the following equation:

$$
F D_{i}=\beta_{0}+\beta_{1} I A E_{i}+\beta_{2} I A R_{i}+\beta_{3} I A T_{i}+\varepsilon
$$

Where $F D_{i}$ is the Fraud Detection variable; $I A E_{i s}$ refers to Internal Audit Efficiency; $I A R_{i}$ represents the Internal Auditor Responsibility variable; ands $I A T_{i s}$ refers to Internal Auditor Training. The above model was empirically tested using linear regression analysis and estimated using the ordinary least squares methodology.

\section{Findings}

\subsection{Descriptive statistics}

The first set of questions in the questionnaire refers to questions that measure the detection of fraud (Table 2). We can observe that detection of unauthorized transactions, employ fraud, and falsifying of financial statements are controlled at a high degree. However, regarding false valuation of company assets we see that detection levels are not that high.

\begin{tabular}{|c|c|c|c|c|c|c|}
\hline \multicolumn{2}{|r|}{ Detection of fraud } & \multicolumn{5}{|c|}{$\begin{array}{c}\text { Frequency } \\
(\%)\end{array}$} \\
\hline & & 1 & 2 & 3 & 4 & 5 \\
\hline \multirow[b]{2}{*}{ V01 } & \multirow{3}{*}{$\begin{array}{l}\text { We are able to detect unauthorized } \\
\text { transactions }\end{array}$} & 0 & 0 & 6 & 80 & 26 \\
\hline & & $\begin{array}{c}0.00 \\
\%\end{array}$ & $0.00 \%$ & $5.36 \%$ & $\begin{array}{c}71.43 \\
\%\end{array}$ & $\begin{array}{c}23.21 \\
\%\end{array}$ \\
\hline \multirow[b]{2}{*}{ V02 } & & 0 & 0 & 10 & 70 & 32 \\
\hline & We are able to detect fraud by employees & $\begin{array}{c}0.00 \\
\%\end{array}$ & $0.00 \%$ & $8.93 \%$ & $\begin{array}{c}62.50 \\
\%\end{array}$ & $\begin{array}{c}28.57 \\
\%\end{array}$ \\
\hline \multirow[b]{2}{*}{ V03 } & \multirow{2}{*}{$\begin{array}{l}\text { We are able to detect falsifying of } \\
\text { financial statements }\end{array}$} & 0 & 0 & 10 & 78 & 24 \\
\hline & & $\begin{array}{c}0.00 \\
\%\end{array}$ & $0.00 \%$ & $8.93 \%$ & $\begin{array}{c}69.64 \\
\%\end{array}$ & $\begin{array}{c}21.43 \\
\%\end{array}$ \\
\hline
\end{tabular}

Table 2: Detection of fraud 
The effect of internal audit effectiveness, auditor responsibility and training in fraud detection

\begin{tabular}{ccccccc}
\hline \multicolumn{2}{c}{ Detection of fraud } & \multicolumn{5}{c}{$\begin{array}{c}\text { Frequency } \\
(\mathbf{\%})\end{array}$} \\
\hline & $\mathbf{1}$ & $\mathbf{2}$ & $\mathbf{3}$ & $\mathbf{4}$ & $\mathbf{5}$ \\
\hline \multirow{2}{*}{ V04 } & $\begin{array}{l}\text { We are able to detect false valuation of } \\
\text { company assets }\end{array}$ & 1 & 16 & 75 & 17 & 3 \\
& 0.89 & 14.29 & $66.96 \%$ & 15.18 & $2.68 \%$ \\
\hline
\end{tabular}

The second set of questions measures internal audit effectiveness. According to the results shown in Table 3, there is a high level regarding the disciplinary consequences to the perpetrators of fraud. Also majority of the respondent agree that that the internal auditing system improve the operation of their business while it prevents mistakes and helps them to effectively detect fraud.

Table 3: Internal audit effectiveness

\begin{tabular}{|c|c|c|c|c|c|c|}
\hline & \multirow[t]{2}{*}{ Internal Audit Effectiveness } & \multicolumn{5}{|c|}{$\begin{array}{c}\text { Frequency } \\
(\%)\end{array}$} \\
\hline & & 1 & 2 & 3 & 4 & 5 \\
\hline \multirow{2}{*}{ V05 } & \multirow{2}{*}{$\begin{array}{l}\text { There are disciplinary consequences } \\
\text { to perpetrators of fraud }\end{array}$} & 0 & 0 & 4 & 65 & 43 \\
\hline & & $0.00 \%$ & $0.00 \%$ & $3.57 \%$ & $58.04 \%$ & $38.39 \%$ \\
\hline \multirow{2}{*}{ V06 } & \multirow{2}{*}{$\begin{array}{l}\text { There are special control services in all } \\
\text { departments of the business }\end{array}$} & 0 & 0 & 2 & 74 & 36 \\
\hline & & $0.00 \%$ & $0.00 \%$ & $1.79 \%$ & $66.07 \%$ & $32.14 \%$ \\
\hline \multirow{2}{*}{ V07 } & \multirow{2}{*}{$\begin{array}{l}\text { The staff of internal auditing is deemed } \\
\text { sufficient for now }\end{array}$} & 0 & 7 & 65 & 36 & 4 \\
\hline & & $0.00 \%$ & $6.25 \%$ & $58.04 \%$ & $32.14 \%$ & $3.57 \%$ \\
\hline \multirow{2}{*}{ V08 } & \multirow{2}{*}{$\begin{array}{l}\text { The internal auditing system improves } \\
\text { the operation of the business }\end{array}$} & 0 & 0 & 7 & 70 & 35 \\
\hline & & $0.00 \%$ & $0.00 \%$ & $6.25 \%$ & $62.50 \%$ & $31.25 \%$ \\
\hline \multirow{2}{*}{ V09 } & \multirow{2}{*}{$\begin{array}{l}\text { The structure of the control system } \\
\text { prevents mistakes }\end{array}$} & 0 & 0 & 9 & 66 & 37 \\
\hline & & $0.00 \%$ & $0.00 \%$ & $8.04 \%$ & $58.93 \%$ & $33.04 \%$ \\
\hline \multirow{2}{*}{ V10 } & \multirow{2}{*}{$\begin{array}{l}\text { The system of internal control operates } \\
\text { effectively in detection of fraud }\end{array}$} & 0 & 0 & 6 & 71 & 35 \\
\hline & & $0.00 \%$ & $0.00 \%$ & $5.36 \%$ & $63.39 \%$ & $31.25 \%$ \\
\hline \multirow{2}{*}{ V11 } & \multirow{2}{*}{$\begin{array}{l}\text { The safeguards of the control system } \\
\text { prevent illegal activities }\end{array}$} & 0 & 0 & 34 & 44 & 34 \\
\hline & & $0.00 \%$ & $0.00 \%$ & $30.36 \%$ & $39.29 \%$ & $30.36 \%$ \\
\hline
\end{tabular}

The next set of questions measure the responsibility of the internal auditor. As it is depicted in Table 4, majority of the respondents agree that the internal auditor has full access to the business records and that errors are reported directly to the administration of the company. 
Table 4: Internal auditor responsibility

\begin{tabular}{|c|c|c|c|c|c|c|}
\hline \multirow{2}{*}{\multicolumn{2}{|c|}{ Internal Auditor Responsibility }} & \multicolumn{5}{|c|}{$\begin{array}{l}\text { Frequency } \\
(\%)\end{array}$} \\
\hline & & 1 & 2 & 3 & 4 & 5 \\
\hline V12 & $\begin{array}{l}\text { The internal auditor has full access to } \\
\text { the business records }\end{array}$ & $\begin{array}{c}0 \\
0.00 \%\end{array}$ & $\begin{array}{c}0 \\
0.00 \%\end{array}$ & $\begin{array}{c}2 \\
1.79 \%\end{array}$ & $\begin{array}{c}64 \\
57.14 \%\end{array}$ & $\begin{array}{c}46 \\
41.07 \%\end{array}$ \\
\hline V13 & $\begin{array}{l}\text { There is independence of the internal } \\
\text { auditor }\end{array}$ & $\begin{array}{c}0 \\
0.00 \%\end{array}$ & $\begin{array}{c}0 \\
0.00 \%\end{array}$ & $\begin{array}{c}2 \\
1.79 \%\end{array}$ & $\begin{array}{c}84 \\
75.00 \%\end{array}$ & $\begin{array}{c}26 \\
23.21 \%\end{array}$ \\
\hline V14 & $\begin{array}{l}\text { There is cooperation of the internal } \\
\text { auditor with the members of } \\
\text { administration }\end{array}$ & $\begin{array}{c}0 \\
0.00 \%\end{array}$ & $\begin{array}{c}2 \\
1.79 \%\end{array}$ & $\begin{array}{c}15 \\
13.39 \%\end{array}$ & $\begin{array}{c}66 \\
58.93 \%\end{array}$ & $\begin{array}{c}29 \\
25.89 \%\end{array}$ \\
\hline V15 & $\begin{array}{l}\text { Internal auditing report directly to } \\
\text { administration the finding errors }\end{array}$ & $\begin{array}{c}0 \\
0.00 \%\end{array}$ & $\begin{array}{c}0 \\
0.00 \%\end{array}$ & $\begin{array}{c}7 \\
6.25 \%\end{array}$ & $\begin{array}{c}88 \\
78.57 \%\end{array}$ & $\begin{array}{c}17 \\
15.18 \%\end{array}$ \\
\hline V16 & $\begin{array}{l}\text { Internal auditing is carried out by staff of } \\
\text { the section of internal auditing }\end{array}$ & $\begin{array}{c}0 \\
0.00 \%\end{array}$ & $\begin{array}{c}0 \\
0.00 \%\end{array}$ & $\begin{array}{l}10 \\
8.93 \%\end{array}$ & $\begin{array}{c}79 \\
70.54 \%\end{array}$ & $\begin{array}{c}23 \\
20.54 \%\end{array}$ \\
\hline V17 & $\begin{array}{l}\text { The administration hires external } \\
\text { auditors to exercise internal auditing }\end{array}$ & $\begin{array}{c}5 \\
4.46 \%\end{array}$ & $\begin{array}{c}76 \\
67.86 \%\end{array}$ & $\begin{array}{c}23 \\
20.54 \%\end{array}$ & $\begin{array}{c}5 \\
4.46 \% \\
\end{array}$ & $\begin{array}{c}3 \\
2.68 \%\end{array}$ \\
\hline
\end{tabular}

Finally, the last set of questions relates to the training of internal auditors. It is noted that internal auditors are often trained on a high scale and are considered to be experienced as they are certified internal auditors and follow international control standards (Table 5).

Table 5: Internal Auditor Training

\begin{tabular}{|c|c|c|c|c|c|c|}
\hline \multicolumn{2}{|r|}{ Internal Auditor Training } & \multicolumn{5}{|c|}{$\begin{array}{c}\text { Frequency } \\
(\%)\end{array}$} \\
\hline & & 1 & 2 & 3 & 4 & 5 \\
\hline V18 & $\begin{array}{l}\text { The staff of internal auditing is trained } \\
\text { constantly }\end{array}$ & $\begin{array}{c}0 \\
0.00 \%\end{array}$ & $\begin{array}{c}0 \\
0.00 \%\end{array}$ & $\begin{array}{l}10 \\
8.93 \%\end{array}$ & $\begin{array}{c}81 \\
72.32 \%\end{array}$ & $\begin{array}{c}21 \\
18.75 \%\end{array}$ \\
\hline V19 & $\begin{array}{l}\text { The staff of internal auditing is } \\
\text { experienced }\end{array}$ & $\begin{array}{c}0 \\
0.00 \%\end{array}$ & $\begin{array}{c}0 \\
0.00 \%\end{array}$ & $\begin{array}{c}3 \\
2.68 \%\end{array}$ & $\begin{array}{c}67 \\
59.82 \%\end{array}$ & $\begin{array}{c}42 \\
37.50 \%\end{array}$ \\
\hline V20 & Internal auditors are certified & $\begin{array}{c}0 \\
0.00 \%\end{array}$ & $\begin{array}{c}0 \\
0.00 \%\end{array}$ & $\begin{array}{c}17 \\
15.18 \%\end{array}$ & $\begin{array}{c}71 \\
63.39 \%\end{array}$ & $\begin{array}{c}24 \\
21.43 \%\end{array}$ \\
\hline V21 & $\begin{array}{l}\text { The international auditing standards are } \\
\text { followed by internal auditors }\end{array}$ & $\begin{array}{c}0 \\
0.00 \%\end{array}$ & $\begin{array}{c}0 \\
0.00 \%\end{array}$ & $\begin{array}{l}11 \\
9.82 \%\end{array}$ & $\begin{array}{c}70 \\
62.50 \%\end{array}$ & $\begin{array}{c}31 \\
27.68 \% \\
\end{array}$ \\
\hline
\end{tabular}

\subsection{Validity and reliability assessment results}

In order to conduct factor analysis we must check the appropriateness of the data collected. First, the size of our sample must be sufficient in order to conduct factor analysis. Hair et al. (1995) suggest that the observations must be at least five times as many as there are variables. The adequacy of sampling is also determined by the Kaiser-Meyer-Olkin's (KMO). KMO values around 0.6 are considered mediocre, values around 0.7 middling, and values around 0.8 or more meritorious (Field, 
2013). Regarding our sample size ( $n=112)$, we adopt Hair's rule for the number of observations to be five times the number of variables in the initial structure. Moreover, the Kaiser-Meyer-Olkin Measure of Sampling Adequacy is 0.803 which indicates high sampling adequacy.

Second, we must check for correlations between the variables. Correlations have to be high (above 0.3), but not too high (for example above 0.8). Also, examining the significance of Barllett's test of sphericity can help us assess the overall significance of the correlation matrix. Finally, assessing multicollinearity between the variables (because the correlations must not be very high), can be conducted by looking at the determinant in the correlation matrix (R-matrix). The determinant must be above 0.00001 in order to denote the absence of multicollinearity between the variables. Table 6 shows that the majority of correlations are above 0.3 and at the same time not above 0.7 which means that factor analysis will be able to extract reliable factors. Finally, Barllett's test of sphericity is significant $(p<=0.000)$ and the Determinant is above the critical value of 0.000 , which indicate the absence of multicollinearity between the variables.

Since the above criteria have been met, we can proceed with the extraction of the factors. Regarding the extraction method, there are several ways to extract factors. The most common are Principal Component Analysis (PCA) and Principal Axis Factoring (PAF). In this study, we are going to use PAF. Although, the differences between PCA and PAF are not significant (Williams et al., 2010; Thomson, 2004), PAF only can "estimate the underlying factors and it relies on various assumptions for these estimates to be accurate. PCA is concerned only with establishing which linear components exist within the data and how a particular variable might contribute to that component" (Field, 2013). 


\section{Table 6: Correlations between initial variables}

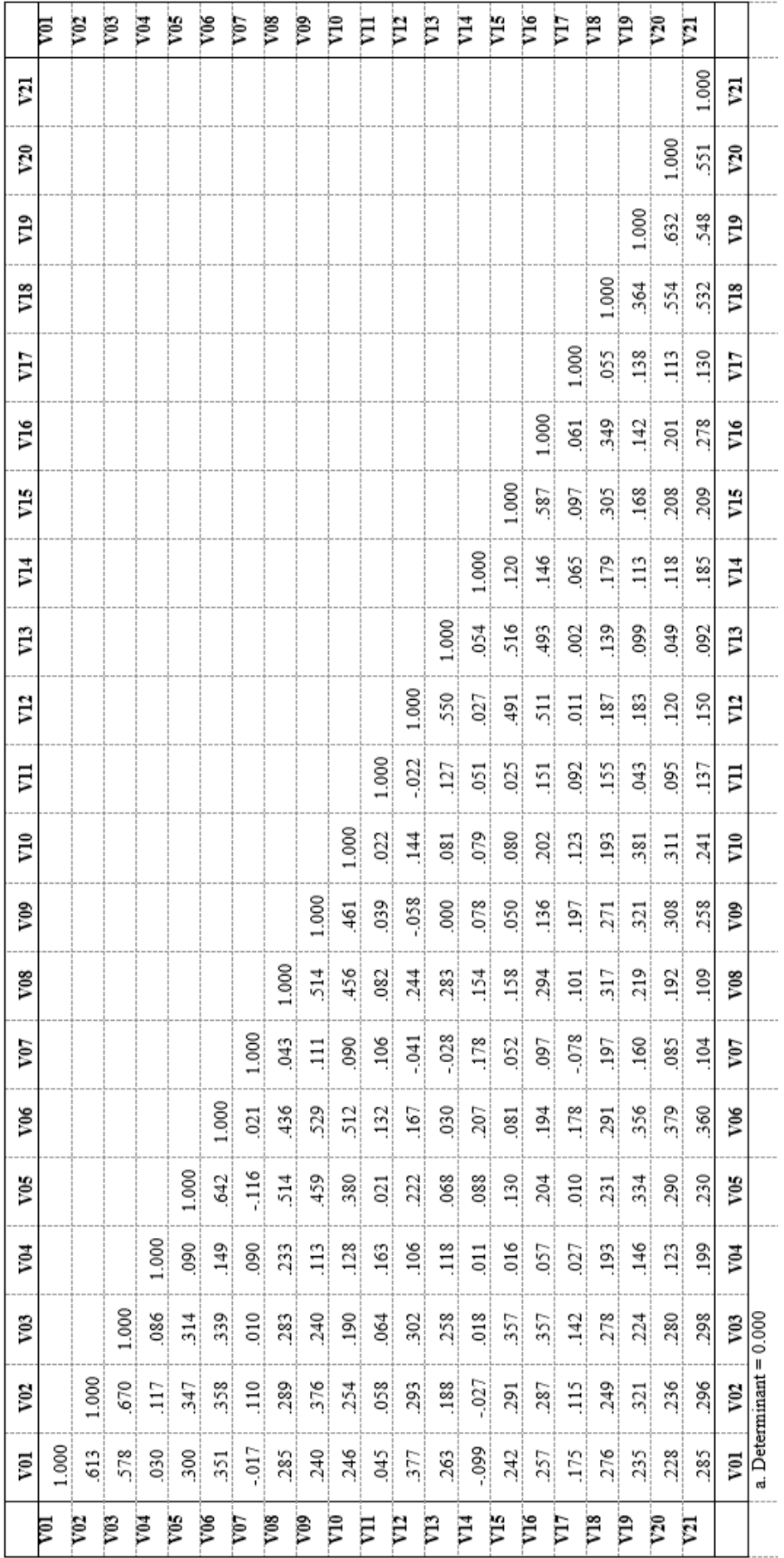


Finally, after the factors have been extracted we can "calculate the degree to which variables load on these factors" (Field, 2013) or the "factor loadings". In examining the factors extracted, some of the variables will have higher factor loadings on a specific factor and smaller loadings on other factors. Regarding the value of factor loadings, values of 0.45 or above are considered to be high enough to be included in a factor (Hair et al., 1995). However, the fact that the same variable has factor loadings in different factors often makes the interpretation of the factor analysis result difficult (Field, 2013). For that reason, before extracting the factors, we must decide the rotation methodology that we will use in our analysis. The rotation of the factors helps us to better interpret the results of the factor analysis. In this study, we will use the Varimax rotation. In Table 7 we can see the results of the factor analysis. In Table 8 we can see the factors as they have been constructed after the analysis.

Regarding the reliability of our survey instrument, we used the internal consistency method. Internal consistency of a structure is measured with the Cronbach alpha coefficient (Cronbach, 1951). According to Nunnally (1978), the construct's Cronbach alpha coefficient should be over 0,800 in order for the construct to yield reliable results. Also, the item-related Cronbach alpha coefficients should be lower than the construct's total Cronbach alpha. A higher item-related Cronbach alpha coefficient means that if the specific item is removed from the construct, then the reliability of the construct will increase. Internal consistency for our factor is depicted in Table 8. As we can observe, the item-related Cronbach alpha coefficients of each variable construct are lower than the construct's total Cronbach alpha. Therefore, we can consider the factors extracted to be reliable.

Table 7: Factor analysis results

\begin{tabular}{ccccc}
\hline & $\mathbf{1}$ & $\mathbf{2}$ & Factor & $\mathbf{3}$ \\
\hline V01 & 0.217 & 0.240 & 0.111 & $\mathbf{0 . 6 5 4}$ \\
V02 & 0.249 & 0.177 & 0.131 & $\mathbf{0 . 7 8 1}$ \\
V03 & 0.182 & 0.284 & 0.152 & $\mathbf{0 . 6 9 7}$ \\
V04 & 0.172 & 0.080 & 0.152 & 0.011 \\
V05 & $\mathbf{0 . 6 7 6}$ & 0.087 & 0.129 & 0.201 \\
V06 & $\mathbf{0 . 6 9 3}$ & 0.009 & 0.263 & 0.224 \\
V07 & 0.003 & 0.008 & 0.192 & 0.009 \\
V08 & $\mathbf{0 . 7 0 0}$ & 0.275 & 0.021 & 0.082 \\
V09 & $\mathbf{0 . 6 5 9}$ & -0.079 & 0.192 & 0.200 \\
V10 & $\mathbf{0 . 5 9 2}$ & 0.059 & 0.210 & 0.089 \\
V11 & 0.062 & 0.088 & 0.131 & 0.000 \\
V12 & 0.089 & $\mathbf{0 . 6 7 7}$ & 0.057 & 0.191
\end{tabular}




\begin{tabular}{ccccc}
\hline & \multicolumn{3}{c}{ Factor } & $\mathbf{3}$ \\
\hline V13 & $\mathbf{1}$ & $\mathbf{2}$ & $\mathbf{0}$ & $\mathbf{4}$ \\
V14 & 0.049 & 0.111 & 0.003 & 0.071 \\
V15 & 0.160 & $\mathbf{0 . 6 9 1}$ & 0.200 & -0.157 \\
V16 & -0.014 & $\mathbf{0 . 6 9 8}$ & 0.196 & 0.168 \\
V17 & 0.147 & 0.001 & 0.107 & 0.120 \\
V18 & 0.123 & 0.232 & $\mathbf{0 . 5 9 7}$ & 0.131 \\
V19 & 0.202 & 0.032 & $\mathbf{0 . 6 4 4}$ & 0.111 \\
V20 & 0.272 & 0.039 & $\mathbf{0 . 7 6 0}$ & 0.169 \\
V21 & 0.224 & 0.094 & $\mathbf{0 . 7 0 6}$ & 0.125 \\
& 0.136 & & & 0.205 \\
\hline
\end{tabular}

Table 8: Internal consistency

\begin{tabular}{|c|c|c|c|}
\hline & Factors/Item Description & $\begin{array}{c}\text { Cronbach's } \\
\text { Alpha }\end{array}$ & $\begin{array}{c}\text { Factor } \\
\text { Loadings }\end{array}$ \\
\hline & Detection of fraud & 0.829 & \\
\hline V01 & We are able to dectect unauthorized transactions & 0.800 & 0.654 \\
\hline V02 & We are able to detect fraud by employees & 0.732 & 0.781 \\
\hline V03 & We are able to detect falsifying of financial statements & 0.754 & 0.697 \\
\hline & Internal audit effectiveness & 0.827 & \\
\hline V05 & There are disciplinary consequences to perpetrators of fraud & 0.789 & 0.676 \\
\hline V06 & There are special control services in all departments of the business & 0.776 & 0.693 \\
\hline V08 & The internal auditing system improves the operation of the business & 0.797 & 0.700 \\
\hline V09 & The structure of the control system prevents mistakes & 0.793 & 0.659 \\
\hline V10 & $\begin{array}{l}\text { The system of internal control operates effectively in detection of } \\
\text { fraud }\end{array}$ & 0.808 & 0.592 \\
\hline & Internal Auditor Responsibility & 0.813 & \\
\hline V12 & The internal auditor has full access to the business records & 0.771 & 0.677 \\
\hline V13 & There is independence of the internal auditor & 0.768 & 0.734 \\
\hline V15 & Internal auditing report directly to administration the finding errors & 0.760 & 0.691 \\
\hline V16 & $\begin{array}{l}\text { Internal auditing is carried out by staff of the section of internal } \\
\text { auditing }\end{array}$ & 0.761 & 0.698 \\
\hline & Internal Auditor Training & 0.819 & \\
\hline v18 & The staff of internal auditing is trained constantly & 0.820 & 0.597 \\
\hline v19 & The staff of internal auditing is experienced & 0.781 & 0.644 \\
\hline v20 & Internal auditors are certified & 0.737 & 0.760 \\
\hline v21 & $\begin{array}{l}\text { The international auditing standards are followed by internal } \\
\text { auditors }\end{array}$ & 0.765 & 0.706 \\
\hline
\end{tabular}

\subsection{Regression analysis}

In order to calculate our regression variables we used the mean value of the items included in each factor. The descriptive statistics for our regression variables are 
presented in Table 9. In order to estimate the regression model, several statistical assumptions of the regression analysis were used. Regarding normality, we applied the Kolmogorov-Smirnov test which showed us that the variables generally do not follow a normal distribution. However, according to Gallego-Alvarez (2012) and Lumley et al. (2002), the absence of a normal distribution does not reduce the validity of the model. Regarding autocorrelation, we conducted the DurbinWatson's test. Our model exhibitsa value of 1.977 which reflects the absence of autocorrelation in the residuals. Finally, in the case of multicollinearity, the values obtained in tolerance have to be high $(0<$ tolerance $<1)$ and the values obtained in the variance-inflation factors (VIF) have to be low (VIF<10). Our model presents tolerances between 0.785 and 0.821 , and VIFs between 1.186 and 1.273 , indicating the absence of multicollinearity.

Table 9: Descriptive Statistics of Regression variables

\begin{tabular}{ccccccc}
\hline N=112 & Mean & $\begin{array}{c}\text { Std. } \\
\text { Deviation }\end{array}$ & Minimum & Maximum & \multicolumn{2}{c}{ Collinearity Statistics } \\
& & & & Tolerance & VIF \\
\hline DF & 4.166 & 0.486 & 3.00 & 5.00 & & \\
IAE & 4.282 & 0.422 & 3.00 & 5.00 & 0.794 & 1.259 \\
IAR & 4.203 & 0.394 & 3.00 & 5.00 & 0.821 & 1.186 \\
IAT & 4.138 & 0.416 & 3.25 & 5.00 & 0.785 & 1.273 \\
\hline
\end{tabular}

Regarding the explanatory power of our model has $\mathrm{R}^{2}$ value of 0.367 for a confidence level of $99 \%(\mathrm{p}<0.01)$. The results from the regression analysis, using the ordinary least squares methodology, are presented in Table 10.

Table 10: Regression analysis results

\begin{tabular}{ccc}
\hline Depedent Variable & DF \\
\hline & Standardized Coefficients & Signifance \\
\hline IAE & 0.292 & 0,001 \\
IAR & 0.274 & 0,001 \\
IAT & 0.261 & 0,003 \\
\hline R Square & 0.367 & \\
\hline F Statistics & 20.850 \\
\hline Durbin -Watson & 1.997 \\
\hline
\end{tabular}

For a confidence level of $99 \%$, internal audit effectiveness, internal auditor responsibility and internal auditor training have positive and statistically significant effect fraud detection. These results allow us to accept hypotheses $\mathrm{H}_{1}, \mathrm{H}_{2}$ and $\mathrm{H}_{3}$. 


\section{Conclusion and recommendations}

During economic crisis, companies are more vulnerable to fraud. People who resort to fraud usually work in the company and are either member of the administration or employees. The incentives that drive them into fraud act are usually the economic benefits that can be earned by falsifying financial statements misevaluating company assets, which often leads to higher bonuses or either types of economic incentives. Moreover, it has also been noticed that there are cases where fraud relates to the failure of the auditors to identify errors in financial statements. That is why the active role of internal auditors in detecting infringements is very important. In order to prevent such actions, each company must create a positive internal audit environment, establish a strong internal auditing system, hire experienced and trusted staff as internal auditors, and continuously train its staff to recognize and detect possible fraud, by developing various prevention strategies. Based on the research presented in the literature review, it is noted that in a company, fraud detection and auditing of corporate activities through the internal audit department is an important part for the proper and continuous operation of the company. There are many companies that have been victims of fraud and the cost of recovering is often high. In order for a company to secure its financial data, it must have an effective control system in order to identify and limit irregularities. A well-trained and experienced auditor can detect misconduct and violations that occur within the company, by using various techniques that can facilitate this control.

The empirical research conducted to investigate fraud detection through internal audit was conducted through a questionnaire sent to companies listed in the Athens Stock Exchange. Data was analyzed through the SPSS statistical package software to verify the interaction of the dependent variable and the independent variables. The dependent variable was the detection of fraud and the independent variables were internal auditing, internal auditor responsibility and internal auditor training. Our analysis shows that audit effectiveness, auditor responsibility and auditor training affect positively and significantly the detection of fraud. These results also agree with the results of the research analyzed in the literature review and especially with the research by Krambia-Kapardis and Papastergiou (2016) who point out the importance of internal audit in the detection of fraud by companies that have been victims of fraud. The first hypothesis suggesting that internal audit effectiveness positively influences fraud identification is consistent with the research by Carcello et al. (2005) and Omoteso and Obalola (2014) who have identified the importance of internal auditing for overseeing business movements and detecting fraud. In addition, the effectiveness of internal audit and its role in identifying fraud has also been examined in the research by Omoteso and Obalola (2014) and Muhtaseb and Yang (2008) who have shown that a correct effective control system can detect fraud. Furthermore, the internal auditor and his sense of 
responsibility plays an important role in identifying fraud as shown in previous research by Vanasco (1998) and Hillison et al.(1999) where the internal auditor is examined as the head of an anti-fraud entity. Finally, the last hypothesis concerning the internal auditor's educational training in fraud detection is also supported by the research of Zanzig and Flesher (2011) and Bierstaker et al. (2012) that training facilitates the work of the internal auditor.

Our results have practical implications both for business and policy makers. Regarding business, the fact that internal auditor responsibility positively affects the detection of fraud, opens a new path for company owners and human resource managers as it is important when hiring an internal auditor to examine whether he has specific traits that can enhance his ability to detect fraud. Moreover, companies could invest in training their internal auditors not only in the established audit procedures but also in developing their sense of responsibility regarding the internal audit procedures. Regarding policy makers, the fact that internal audit effectiveness positively affects fraud detection should motivate the adoption of legislation that promotes the use of internal audit in business and offers incentives for accountants and audit practitioners to enhance their abilities for fraud detections. These incentives could take the form of seminars or workshops that could be partially funded by the ministry of economics or other relevant government departments. Also collaborative workshops between internal private auditors and external public auditors could provide the basis for developing more effective auditing procedures which could facilitate the work of both internal and external auditors.

Our research has a number of constrains. The main limitation is the limited target population of the investigation. Accordingly, the number of respondents to the questionnaire can also be considered limited in relation to other studies. An important limitation also involves company employees' responses which are based on their views, without it being clear if these views were objective and unbiased. It is proposed to carry out further research to analyze the above relationships and to understand the important role of internal auditing in the detection of fraud. Due to the limited target population, this research could take the form of a case study of specific companies and how they implement internal audit procedures. Such a methodology, although it does not offer generalized results, it could shed light on the specific factors that can help companies to detect fraud and to implement prevention as well as recovery processes against it. 


\section{References}

Alvarez, I. G. (2012) "Impact of CO2 emission variation on firm performance", Business Strategy and the Environment, vol. 21(7): 435-454

Balaciu, D. E., Bogdan, V., Feleaga L. \& Popa A. L. (2014) "Colorful approach regarding creative accounting. An introspective study based on the association technique", Accounting and Management Information Systems, vol. 13(4): 643-664

Balaciu, D. E., Bogdan, V., Mester I. T. \& Gherai D. (2012) "Empirical evidences of Romanian auditors' behavior regarding creative accounting practices", ccounting and Management Information Systems, vol. 11(2): 213-238

Bedard, J., Simnett, R. \& De Voe-Talluto J. (2015) “Auditors' consideration of fraud: How behavioral research can address the concerns of standard setters", Advances in Accounting Behavioral Research, vol. 4: 77-101

Bekiaris M., Efthymiou T. \& Koutoupis A. (2013) "Economic crisis impact on corporate governance \& Internal Audit. The case of Greece", Corporate Ownership, Control, vol. 11(1): 55-64

Bierstaker, J., Hunton, J. \&Thibodeau, J. (2012) "Does Fraud Training Help Auditors Identify Fraud Risk Factors?", Advances in Accounting Behavioral Research, vol. 15: 85-100

Button, M., Blackbourn, D., Lewis, C. \& Shepherd, D. (2015) "Uncovering the hidden cost of staff fraud: an assessment of 45 cases in the UK", Journal of Financial Crime, vol. 22(2): 170-183

Carcello, J. V., Hermanson, D. R. \& Raghunandan, K. (2005) "Factors associated with US public companies' investment in internal auditing", Accounting Horizons, vol. 19(2): 69-84

Carmines, E. \& Zeller, R. (1979) Reliability and Validity Assessment, Series: Quantitative Applications in Social Sciences", (No. 07-17), Sage Publications, Newbury Park, CA.

Coram, P., Ferguson, C. \& Moroney, R. (2008) "Internal audit, alternative internal audit structures and the level of misappropriation of assets fraud", Accounting and Finance, vol. 48: 543-559

Cronbach, L. J. (1951) "Coefficient alpha and the internal structure of tests", Psychometrika, vol. 16(3): 297-334

DeZoort, T. \& Harrison, P. (2008) "An Evaluation of Internal Auditor Responsibility for Fraud Detection", The Institute of Internal Auditors Research Foundation

Drogalas, G., Karagiorgos, T. \& Arampatzis, K. (2015) "Factors associated with Internal Audit Effectiveness: Evidence from Greece", Journal of Accounting and Taxation, vol. 7(7): 113-122.

El-Sayed Ebaid, I. (2011) "Internal audit function: an exploratory study from Egyptian listed firms", International Journal of Law and Management, vol. 53(2): 108-128 
Field, A. (2013) Discovering statistics using IBM SPSS statistics, Sage

Forza, C. (2002) "Survey research in operations management: a process-based perspective", International Journal of Operations \& Production Management, vol. 22(2): 152-194

Gaganis, C. \& Zopounidis, K. (2008) Recognition of Counterfeit Accounts, Kleidarithmos Publications, Athens

Hair, J., Anderson, R., Tatham, R. \& Black, W. (1995) Multivariate Data Analysis, 4th ed., Prentice-Hall, Englewood Cliffs, NJ

Hammersley, J. S., Johnstone, K. M. \& Kadous, K. (2011) "How do audit seniors respond to heightened fraud risk?", Auditing: A Journal of Practice\& Theory, vol. 30(3):81-101

Hillison, W., Pacini, C. \& Sinason, D. (1999) "The internal auditor as fraud buster”, Managerial Auditing Journal, vol. 14(7): 351-363

IIA (1999) "A Vision for the Future: Professional Practices Framework for Internal Auditing", The Institute of Internal Auditors Research Foundation, Altamonte Springs, FL.

Krambia-Kapardis, M. \& Papastergiou, K. (2016) "Fraud victimization in Greece: room for improvement in prevention and detection", Journal of Financial Crime, vol. 23(2): 481-500

Lendez, A. \& Korevec, J. (1999) "How to prevent and detect financial statement fraud", The Journal of Corporate Accounting and Finance, pp. 47-54

Lumley, T., Diehr, P., Emerson, P.S. \& Chen, L. (2002) "The importance of the normality assumption in large public health data sets", Annual Review of Public Health, vol. 23:151-169

McKee, T. (2006) "Increase your fraud auditing effectiveness by being unpredictable", Managerial Auditing Journal, vol. 21(2): 224-231

Monisola, O. (2013) "Effect of internal audit on prevention of frauds, errors and irregularities in corporate organisation", Research Journal of Finance and Accounting, vol. 4(19): 103-108

Muhtaseb, M. \& Yang, C. (2008) "Portraits of five hedge fund fraud cases", Journal of Financial Crime, vol. 15(2): 179-213

Nardo, M. (2011) "Economic crime and illegal markets integration: a platform for analysis", Journal of Financial Crime, vol. 18(1): 47-62

Nunnally, J. (1978) Psychometric Theory, 2nd ed., McGraw-Hill, New York, NY.

Omoteso, K. \& Obalola, M. (2014) "The role of auditing in the management of corporate fraud", Ethics, Governance and Corporate Crime: Challenges and Consequences, vol. 6: 129-151

Petrascu, D. \& Tieanu, A. (2014) "The role of internal audit in fraud prevention and detection", Procedia Economics and Finance, vol.16: 489-497

Petrascu, D. \& Tamas, A. (2013) "Internal audit versus internal control and coaching", Procedia Economics and Finance, vol. 6: 694-702

Rezaee, Z. (2005) "Causes, consequences and deterrence of financial statement fraud”, Critical Perspectives on Accounting, vol. 16(3): 277-298 
Saraph, J. V., Benson, P. G., \& Schroeder, R. G. (1989) "An instrument for measuring the critical factors of quality management", Decision Sciences, vol. 20(4): 810-829

Spathis, C. (2002) "Detecting false financial statements using published data: some evidence from Greece", Managerial Auditing Journal, vol. 17: 179-191

Thompson B. (2004) "Exploratory and confirmatory factor analysis: understanding concepts and applications", Washington, DC: American Psychological Association

Vanasco, R. (1998) "Fraud auditing”, Managerial Auditing Journal, vol. 13(1): 4-71

Westhausen, H. (2017) "The escalating relevance of internal auditing as anti-fraud control", Journal of Financial Crime, vol. 24(2): 322-328.

Williams, B., Onsman, A., \& Brown, T. (2010) "Exploratory factor analysis: A five-step guide for novices", Australasian Journal of Paramedicine, vol. $8(3): 1-13$

Zanzig, J. \& Flesher, D. (2011) "Internal auditors speak out on controlling employee fraud", Research on Professional Responsibility and Ethics in Accounting, vol. 15: 225-250 